\title{
UNIVERSITYOF
}

FORWARD

THINKING

WESTMINSTER用

WestminsterResearch

http://www.westminster.ac.uk/westminsterresearch

\section{Assessing the value dimensions of social enterprise networks}

Granados, M. and Rivera, A.M.

This article is ( ) Emerald and permission has been granted for this version to appear here http://westminsterresearch.wmin.ac.uk/18411/

Emerald does not grant permission for this article to be further copied/distributed or hosted elsewhere without the express permission from Emerald Group Publishing Limited.

The final, published version in International Journal of Entrepreneurial Behaviour \& Research, doi: 10.1108/IJEBR-09-2016-0313, 2017 is available at:

https://dx.doi.org/10.1108/IJEBR-09-2016-0313

The WestminsterResearch online digital archive at the University of Westminster aims to make the research output of the University available to a wider audience. Copyright and Moral Rights remain with the authors and/or copyright owners.

Whilst further distribution of specific materials from within this archive is forbidden, you may freely distribute the URL of WestminsterResearch: ((http://westminsterresearch.wmin.ac.uk/)).

In case of abuse or copyright appearing without permission e-mail repository@westminster.ac.uk 


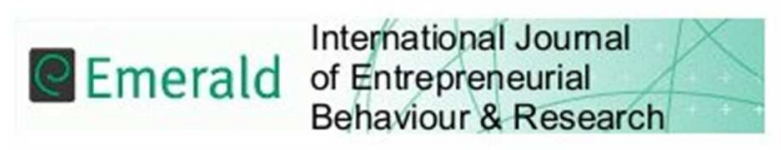

\section{Assessing the value dimensions of social enterprise networks}

\begin{tabular}{|r|l|}
\hline Journal: & International Journal of Entrepreneurial Behavior \& Research \\
\hline Manuscript ID & IJEBR-09-2016-0313.R1 \\
\hline Manuscript Type: & Research Paper \\
\hline Keywords: & Social enterprise, Networks, Knowledge sharing, Social enterprise networks \\
\hline \multicolumn{2}{|c}{} \\
\hline
\end{tabular}

SCHOLARONE $^{\text {m }}$
Manuscripts 


\title{
Assessing the value dimensions of social enterprise networks
}

\begin{abstract}
Purpose: Despite the importance gained by social enterprises (SEs) and the increased number of social enterprise networks (SENs) in the UK, there is a paucity of research into the role of these networks in enhancing the sector and creating value. This paper provides empirical evidence assessing this value.
\end{abstract}

Design/methodology/approach: The assessment and insights were derived through a concurrent mixed method data collection strategy with 241 responses from members of SEs in the UK.

Findings: In terms of frequency, the use of SENs is still sporadic, denoting an immature stage of network lifecycle development. Moreover, it was identified that usage was affected primarily by the perceived usefulness of the information available. The ultimate value created was primarily of an informative nature rather than knowledge exchange.

Practical implications: A framework is developed describing the structure, content and interaction dimensions of value of SENs. The understanding of this value offers opportunities to shape government interventions and current practices of SENs in assisting SEs and providing an active, knowledge-sharing community.

Originality/value: By exploring the value perceived by social entrepreneurs of being part of a SEN, the paper considered an under-researched area of SE literature that can maximised the impact of the sector.

Keywords: Social enterprise, social enterprise networks, networks, knowledge sharing Article classification: Research paper 


\section{Introduction}

The social enterprise (SE) sector in the UK has developed rapidly in the last decade, and is still growing at a very fast pace (Cabinet Office, 2016; Villeneuve-Smith and Temple, 2015). Due to its social and collective nature, the greater part of its operations are based on networking and knowledge sharing and thus creating a new participatory culture of collaboration, which should facilitate cross-organisational knowledge management practices (Granados et al., 2016; Haugh, 2007; Henry, 2015; Meyskens et al., 2010; Seelos et al., 2011). Thus, for the past few years the sector has seen the proliferation of social enterprise networks (SENs), most of them organised geographically, and on a membership based scheme. They provide a much needed, tailored, business support for the sector, as well as an online community of people sharing the same vision. However, there is still a need to understand the main characteristics of these networks, that is, what is the value added to SEs and at what stage are these networks in their development.

This research aims to support this understanding by identifying, from the perspective of social entrepreneurs (the end users), what is the value that SENs are creating for the UK SE sector. More specifically, the study evaluates whether this value is related only to communications and keeping members informed, or whether it also involves an active knowledge sharing community of practice, working together beyond each organisational unit, to create an online, cross-sector, knowledge management platform.

This evaluation was conducted with a concurrent mixed method data collection strategy using 241 responses from senior members of SEs in the UK to an online survey questionnaire. The paper starts by considering the literature in two major areas related to providing value for SEs; it then proceeds to argue the methodology utilised for the survey undertaken and discusses the results through standard statistical analytics and content analysis. Finally, the paper considers the answers to the research questions by providing a framework and makes suggestions as to further work.

\section{Social enterprises: A transformative business model}

Defining SEs is considered a complex problem, partially because of two reasons (Alter, 2003; Dart, 2004; Defourny and Nyssens, 2006; Haugh, 2005; Hockerts, 2006; Martin and Thompson, 2010; Peattie and Morley, 2008; Teasdale, 2012). The first one is related to geographical issues. Even under the same school of thought that originated initially in Europe (Defourny and Nyssens, 2010), SEs are presented and delivered in different political, economic and social contexts. This shapes and varies their processes, motivations and, even, legal forms (Kerlin, 2009, 2010; Thema et al., 2015). A second reason is because of 
the nature of the organisation, income generation methods, and the multitude of services they provided. These difficulties have led to a continuous and never-ending debate among practitioners and academics over the exact definition of SE. This has generated conflicts in measuring its activities, comparing its results, and transferring innovative solutions and experience from one another.

Since this research was undertaken in the UK, the study follows the definition given by the former UK Department of Trade and Industry, now known as the UK Department for Business, Energy and Industrial Strategy. A SE is 'a business with primarily social objectives whose surpluses are reinvested for that purpose in the business or in the community, rather than being driven by the need to maximise profit for shareholders and owners' (DTI, 2002).

This definition implies the existence of what has been referred to as a 'triple bottom line', a structure that, according to Martin and Thompson (2010), includes the following elements: social aims, social ownership, and enterprise centred. This makes SEs a hybrid business model difficult to manage, as all their activity has to be balanced between being a profitable enterprise, and creating social value, which opens the door to countless debates around profit distribution, ownership, governance, and the relationship between mission and services (Battilana and Lee, 2014; Doherty et al., 2014; Ebrahim et al., 2014; Hoogendoorn et al., 2010; Santos, 2012).

SEs are transformative business models, not only as a result of how they redistribute profits, but also because they are redefining business practices, and the relationships of businesses and the community (Spear, 2006). For that purpose, new legal structures have been developed, adding another element of complexity to this sector. Nonetheless, based on the UK government statistics, the impact of these organisations has significantly increased in recent years, with an estimated 741,000 UK SEs in 2014 , an increase of $8 \%$ in relation to 2012, employing an estimated 2.27 million people, and increase of $11 \%$ in relation to 2012 (Cabinet Office, 2016). Although these figures have been challenged by academics arguing that governments can manipulate survey methods to support political decisions, it is still recognised a positive trend in their growth (Teasdale et al., 2013). This trend is directly related to the inclusion of new social entrepreneurs ahead of innovative social businesses, and the allocation of suitable resources for this purpose (Peattie and Morley, 2008; Shah, 2009). If only the financial conditions are considered, the scarcity of these resources creates a significant problem, which has a clear, direct impact on the access to new funding capital, but also an indirect effect in the supply of support services to the sector. Equally important is how SEs can inform themselves of the existence of these resources, and the creation of a 
non-financial, resource-based network that facilitates the sharing of knowledge within the sector (Peattie and Morley, 2008; Spear, 2006).

Though embryonic a few years back, business support resources are now widely available for SEs. The general perception of their effectiveness has changed significantly in the recent years, from being seen as poorly focused (Hines, 2005); to not sufficiently tailored (Leahy and Villeneuve-Smith, 2009); to slightly excessive (Mawson, 2010). This evolution in the number of options available has also seen a professionalisation of the services, moving the sector from informal social networking to more established and defined bodies of resources and information, which mainly take the shape of online networks. These networks, however, are still not well understood and there is a need to study further these opportunities and the potential value created by SENs in supporting the development and growth of the SE sector.

\section{Value of networks for social enterprises}

SEs normally operate in uncertain and innovative fields, which requires experience and new knowledge to achieve innovative solutions to social and environmental problems (Weber et al., 2013). Thus, SEs are looking for external actors to acquire this knowledge, which can be very demanding and requires time and effort from both exchange actors, especially when the knowledge is sensitive, complex, privately held and difficult to transfer (Leonard-Barton, 1995; Milton, 2007; Teece et al., 1997; Yli-Renko et al., 2001). Therefore, organisations as SEs are more likely to participate in knowledge sharing and transfer when there are well established communication channels resulting from frequent interactions (Christopoulos and Vogl, 2015; Weber et al., 2013). These channels and interaction can occur in the frame of SEN.

A network is normally considered in the entrepreneurship literature as a group of actors that have frequent and enduring relationships with one another, and where information exchange and trust exists (Hoang and Antoncic, 2003). In relation to SEs, researchers have recognised the great potential offered by networks in the development of sustainable SEs, especially in supporting the acquisition of resources, facilitating coproduction and partnerships, identifying opportunities, and gaining of legitimacy (Austin et al., 2006; Dixon and Clifford, 2007; Doherty et al., 2014; Di Domenico et al., 2010; Farmer et al., 2012; Meyskens et al., 2010; Sharir and Lerner, 2006; Shaw and Carter, 2007; Stam et al., 2014). As is the case in any organisation, SEs are normally resource dependent and require to develop potential relationships with institutions and organisations in their environment that can provide them access to those resources. Some of those resources can include funding, 
assets (land and offices), human resources, or specialised knowledge (Peattie and Morley, 2008).

However, the development of an established business support stream for SEs has been perceived by SEs as lacking an understanding of the SE concept and the principles on which they are based (Office of the Third Sector (OTS), 2007; Peattie and Morley, 2008). As the sector started growing and maturing, the increase in the number of business support services available was initially seen as a positive trend, but in the long term only created more confusion, as these resources were very enterprise focused but not social enough to respond adequately to the problems of the sector (Hines, 2005; Mawson, 2010).

There was a lack of understanding between business support providers and SEs, and a different language being spoken (Hines, 2005), so it became clear that for this new hybrid model appearing in the business scene, there was a greater need to develop more specific and tailored tools that would support their transformative business practices, whilst also taking into account their social dimension, and locality (Lyon and Ramsden, 2006; Peattie and Morley, 2008). It became vital to build up formal business support networks that would complement the existing informal ones, as a way to standardise the sector and the public policy debate, in order to move it forward to a wider scene (Shah, 2009). While informal networks are those that give access to other social actors, and key partners are in the process of creating new knowledge and sharing it with others for its dissemination (Martin and Thompson, 2010), the formal network involves organisations with economic responsibilities, such as central government, local authority, and community development members (Haugh, 2007). The development and enhancement of these formal networks requires an understating of their main characteristics and the elements that support value creation for SEs. Recent studies and research projects have been investigating the role of stakeholder networks in SEs (Hazenberg et al., 2016), as well as the role of networks in shaping different SE models around the world (see ICSEM and EFESEIIS projects for a detailed description of these models). Even though these studies agreed in the important role of stakeholder networks for SE development, they recognised the paucity of research on how different networks are supporting the sector and what are their main characteristics.

In order to determine the value created by networks, entrepreneurship literature has recognised the crucial role of networks in providing social capital (Neergaard et al., 2005) and opportunity development (Hormiga et al., 2011). Although researchers are still arguing about the relationship between social capital and social networks, it is recognised that social capital includes the tangible and intangible resources acquired through networks (Greve and 
Salaff, 2003). Consequently, the social capital value of a networks is defined by both its form and content (Burt, 1997). This perception of value relates to what Neergaard et al. (2005) have defined as the three network dimensions based on social capital, social network and social support theory: the network structure, network interaction and network content. The network structure refers to location of actors in the network, the interaction refers to the intensity, frequency and direction of interactions in the network, and content is considered the meaning that people attached to relationships. Concurring with Burt (1997), Hoang and Antoncic (2003) agreed that content is regarded as one of the most important elements when assessing for the first time the value created by networks. To assess the content of relationships, Mitchell (1969) argued that because content may not be directly observable, information can be considered as a way of interpreting the meaning which people attached to relationships. In the case of formal networks, researchers have associated the content also with the information, advice and emotional support provided by networks to their members (Hoang and Antoncic, 2003; Neergaard et al., 2005). Following information quality theories, there are certain characteristics of information that can permit the assessment of its value (Lee et al., 2002; Miller, 1996). These are the perception of usefulness of the information provided, the quality of this information, and how easy is to access the information. Taking this into account, this study argues that the current use of SENs by SEs is regarded by their perception of content, most specifically, their perception of usefulness, quality and ease of access to the information, advice and emotional support provided. Consequently, the following hypotheses are proposed:

Hypothesis 1: The frequency of use of SEN is determined by the perceived usefulness, quality and ease of access of the information available on SEN.

Hypothesis 1.a: The frequency of use of SEN is determined by the perceived usefulness of the information available on SEN.

Hypothesis 1.b: The frequency of use of SEN is determined by the perceived quality of the information available on SEN.

Hypothesis 1.c: The frequency of use of SEN is determined by the perceived ease of access of the information available on SEN.

\section{Methodology}

Based on the research aim and hypotheses presented in the previous sections, this study follows a concurrent mixed method data collection strategy, which allows the collection of 
both quantitative and qualitative data that will exhibit the view of the relationship between theory and practice (Creswell, 2014; Creswell and Plano Clark, 2011; Tashakkori and Teddlie, 2010). Although the hypotheses form the bases of the study, there are certain perceptions of value that cannot be easily measured with quantitative indicators and need further explanation and justification. Thus, the quantitative and qualitative data held equal status throughout the data collection, analysis, and interpretation.

The population for this research is SEs in the UK. Due to the difficulty in deciding which enterprises were really a SE, and to access the SEs that follow the UK definition used in this study, the sample frame for this research considered over 600 SEs from across the UK that attended the event 'Voice 12', the UK's biggest SE event of the year. The research was carried out using a single respondent to represent each organisation, often the CEO, a senior manager, or someone within the business development team. Even though this might not represent the full profile of an organisation's relation to SENs, it does provide an individual insight to the entrepreneurs and their relationship to the network of choice.

The data collection was conducted through a self-completion online questionnaire. The advantages of this data collection format lies in the ease of access to a great number of SEs in different locations across the country, the speed to response, and the simplicity of administration of large quantities of responses (Bryman and Bell, 2015). The questionnaire included demographic questions about the organisation, and questions that allowed the hypotheses to be tested, such as, measures of frequency, perceived 'usefulness', perceived 'quality' and perceived 'ease of access' expressed as Likert-type scale questions. Further categorical questions on perceived value, selection criterion and purpose were also included to enhance the data analysis process. Each categorical question in the questionnaire had the option of 'other' as an open-ended and unlimited comment field. Additionally, a general open-ended question was included at the end to provide further explanation of respondents' answers to the Likert-type scale questions.

The SEs were surveyed over a period of two months, with two follow-up email reminders inbetween, to increase response rates. After the data collection period was over, the initial number of responses obtained was 260 . That number was later cleaned according to nonresponses of the full questionnaire, and essential missing data, which brought the number of usable questionnaires down to 241 , equivalent to a $40 \%$ response rate. The quantitative data collected was analysed using standard parametric correlation and multiple linear regression that allowed for hypothesis testing. The qualitative data collected from the openended questions were more challenging to analysed because they were normally brief, 
different, sparse and without clear context. Moreover, the format did not allow for immediate follow-up questions to improve understanding. Nonetheless, these questions forced respondents to express themselves in more of a concise format while at the same time giving them the opportunity to explain themselves in a short narrative form (Jackson and Trochim, 2002). Content analysis is normally recommended for analysing open-ended responses in questionnaire because it helps to reduce text data into manageable summary categories or themes for making inference about a sample (Krippendorff, 2012). Thus, content analysis was conducted on 161 responses to the open-ended questions. Following Smyth et al. (2009) approach, coding proceeded in four steps. First, the authors coded 10 percent of the responses of each open-ended question to develop a list of coding rules that established what was to be coded as free-codes, trying to remain faithfully to respondents' terms. Second, one of the authors used the established rules to code the remaining responses. Third, the other author independently coded 10 percent of the responses to verify the coding process. Finally, the emerging codes were combined into higher level categories, following Gioia et al. (2013). This allowed to identify similar patterns in the responses, such as positive and negative comments.

\section{Results}

The organisational characteristics of the sample followed similar patterns already identified in government statistics about SEs in the UK (Villeneuve-Smith and Temple, 2015). Most SEs surveyed fall into the category of micro (59\% with fewer than 10 employees) and small enterprises (25\% with between 11 and 49 employees). Only $16 \%$ were considered medium/large enterprises (50 and more employees). A cumulative $73 \%$ of the SEs surveyed have a yearly turnover of less than $£ 1 \mathrm{~m}$, with $31 \%$ having less than $£ 100 \mathrm{k}$. In terms of geographical distribution, the questionnaire used a classification of regions provided by 'Voice 12', which included South West England, North West England, East of England, Midlands, London, Scotland, Wales and Northern Ireland. Most respondents were from London (26.6\%) and Midlands (19\%). The least represented regions were Northern Ireland with $2.1 \%$ and Wales with $2.9 \%$.

As indicated in the methodology section, categorical questions were asked in regards to criteria for selecting SENs, purpose and the value perceived of these networks. The responses are presented in Table 1.

\section{Insert Table 1 here}


Table 1 shows that $54.8 \%$ of SEs indicated that the main criteria they use to choose a network, is based on the locally/regionally based nature of the SEN in question. This shows the importance of regionalism in the UK, but also the nature of SEs as local solutions for local social issues arising within the community, and the need for different support tools that address those local needs, as previously highlighted by SE researchers (Lyon and Ramsden, 2006; Mawson, 2010; Office of the Third Sector (OTS), 2007; Peattie and Morley, 2008). For this question, 54 participants selected 'other' option and provided detailed description of these criteria. By analysing the answers, three themes were identified. These are:

- Content: respondents referred to the relevance of the content, the discussion, the quality of the information, how easy was to use the network and the importance of being sector specific;

- Credibility and reputation: for some participants, the main criteria for selecting a SEN were their credibility, based on the quality of leaders and thinkers, as well as their established reputation. These can be related to the concept of 'Prestige', which was included as a category in the question and was ranked as the third reason for selecting SEN; and

- Opportunity potential: some participants select a SEN because of the potential business development opportunities they can offer, such as networking opportunities, and the opportunity to improve their customer base.

The purpose behind their use of SEN shows that $71.4 \%$ of SEs use SENs for sector news update, whilst another $50.6 \%$ do so to develop their contacts. A further $46.9 \%$ do so to access the latest research and reports about the sector, and $42.7 \%$ see them as an opportunity to access new sources of funding. This concurred with previous research that emphasised how entrepreneurs used initially the networks to get resources, such as information and financial opportunities (Freeman et al., 1983; Haveman and Rao, 2006; Ruef and Scott, 1998). As will be demonstrated later in the paper, these findings demonstrate how SEs are using SEN mainly for information purposes. When the answers to the 'other' option were analysed (16 responses), purposes such as 'opportunity spotting', 'marketing' and 'avoiding repetition' were included. These recognised how some SEs can use the SEN to promote themselves and to know what others are doing so they do not repeat the efforts.

When it comes to value creation, $66.4 \%$ of SEs believed these networks create value for the sector by keeping it informed of the latest news, and facilitating the communication between its members (46.9\%). $48.1 \%$ think SENs generate a platform for knowledge sharing across 
the sector. The answers provided in the 'other' category indicated how SEN created value also by allowing best practices to be shared, by promoting the sector and raising awareness, and by providing 'a feeling of inclusiveness and support to front an important pioneering cause'. Although there was a general positive perception of the value these networks created, 14 participants believed SENs do not create value at all, as a respondent mentioned 'they actually destroy it by delivering a poor impression of the sector'.

The analysis of the previous three questions provided a first overview into the perception of value of SENs, highlighting issues around content and information, but also about credibility, sector awareness and emotional support. To assess and test the four hypotheses proposed in this paper, which are mainly related to content, firstly a reliability test was conducted. This test establishes the internal consistency of the scale between the identified dependent and independent variables only (Hair et al., 2010; Pallant, 2013). The reliability coefficient obtained (Cronbach's alpha) was 0.837 , which is considered very acceptable (Hair et al., 2010), and supports further analysis of the variables. A further standard multiple regression analysis was run to explore the relationship between all independent variables together ('usefulness', 'quality', and 'ease of access'), over the dependent variable ('frequency of usage') to support or reject Hypothesis 1. Hypotheses 1.a, 1.b and 1.c were tested with correlation analysis. Basic descriptive statistics, and regression and correlation coefficients are shown in Table 2.

\section{Insert Table 2 here}

Based on the findings in Table 2, each of the predictor variables had a significant $(p<.01)$ correlation with frequency of usage of SEN, confirming Hypotheses 1.a, 1.b and 1.c. When evaluating the regression results, it was evident by interpreting R2 that the three-variable model was able to account for $27 \%$ of the variance in 'frequency of usage' of SEN. Although the coefficient of determination was not very strong, the regression model in this case was significant (F-test, $p<.01$ ), which allowed the support of Hypothesis 1 , in that the overall relationship between the predictors (perceived 'usefulness', 'quality' and 'ease of access' of the information available) and the frequency of use of SEN is significant. However, when analysing the results of the t-test, only the predictor variable 'usefulness of informatio'n contributed significantly to the ability to estimate the frequency of usage of SEN (t-test, $p<$ .01).

It is possible to establish that the 'frequency of usage' of SENs is positively affected by a combination of factors including 'usefulness of information', 'quality of Information', and 'ease of access' to that information; of which, the perceived 'usefulness of information' has the 
biggest impact on user's behaviour and frequency of use. However, the overall variance that this explains is relatively low, only $27 \%$, which means that other kind of variables should be considered in a further analysis to get a better understanding of the model.

As was indicated in the methodology, one open-ended question was included in the questionnaire at the end, asking respondents to provide further explanation of their answers to the Likert-type scale questions. A total of 101 responses were collected.

The result of the content analysis of these responses is presented in Figure 1 and Figure 2. Initially, two higher level categories, positive and negative comments, were identified. Among the negative comments (37) (Figure 1), respondents' perceptions concurred with the quantitative findings in the way that the usefulness of the information received was a main reason they did not perceived value from the SEN. The positive comments (64) (Figure 2) provided insights into members' perceptions of SENs, describing in detail positive characteristics of content or information quality. Moreover, respondents specified detailed accounts of other important ways SENs provided value. These areas include business development opportunities and networking, emotional support and knowledge sharing, SE promotion and marketing, and the SEN structure.

\section{Insert Figure 1 here}

\section{Insert Figure 2 here}

\section{Discussion}

The aim of this research was to identify, from an end user perspective, the value that SENs are creating for the SE sector, and to assess whether this value was only related to communications and keeping members informed of what is happening in the sector, or is there a more active knowledge sharing community, working together beyond each organisational unit. The results of the data analysis offer interesting findings that allow the study to provide an answer to these questions.

Regarding the features of a network discussed at the beginning of the paper, the SEN content was assessed in terms of the impact of perceived usefulness, quality and ease of access to the information provided in the frequency of use of the SEN. As seen from the survey results, only $5.8 \%$ of surveyed SEs said they use SENs, whether nation-wide or regional, every day. A cumulative $26.5 \%$ said they use them on a regular basis, either every day or twice a week, but the majority $(55.2 \%)$ only use SENs three to four times a month, or 
a few times a year. According to Stalder (2006, p. 177) 'this sporadic or short-term interaction is not enough to form a distinct entity, that is, a network', as it is 'precisely the formation of distinct patterns of interaction over time that gives networks their identity'. This indicates that when SEs use online support tools, whether general resources or SENs, they do so looking out for specific information when they require it, but not as a day to day core element of their business strategy.

The multiple regression analyses point out that even if all variables have a degree of correlation and effect on the frequency of usage, this is mostly related to, and affected by, the perceived usefulness of the information, rather than the quality or ease of access to it. This shows that, at this stage, users are looking for functional information, rather than complex or sophisticated analysis on the nature of the sector. Whether the information is good or average is of secondary importance to this young, developing sector, which fundamentally needs practical information, and real case scenarios from which to learn, and acquire new tools to make their businesses grow. This was evident in the analysis of the open-ended question, where respondents highlighted the need to include support on how to implement policies, share case studies, best practices, and other SEs strategies and experiences.

I found the London Network to be lacking in any useful information, I want the latest policy and implementation progress not a list of existing projects and service'

Regarding the purpose of use of the SENs, the results demonstrated how varied the motivations behind the usage of SENs are, but also indicated a strong inclination for the communication side of networking rather than the learning dimension of knowledge sharing. This was reinforced with comments provided in the open-ended questions were respondents mentioned better business development tools to learn from, rather than mainly news, as well as more opportunities to establish peer-to-peer relationships. As one respondent explained:

'Sometimes feel I'm going around in circles learning the same things and asked to look at this link or that website... what would be really useful is being able to chat to somebody for advice as soon as possible and not have to be on a waiting list for 6 months!'

When questioned about value perception, opinions vary significantly, and the perception fluctuates from either being very good and effective, to very poor and irrelevant. The SENs are creating value to the sector by keeping each member informed of what is going on around them, however, this information is also perceived to be generic and repetitive, which creates the opposite effect in the perception of value. Useful information seems to be harder 
to find, requiring more time to be invested in the search, and is inconsistent across the different networks. This has an impact in the perceived value, as it implies that the entrepreneurs must invest more of their time in engaging with these support tools, without sometimes seeing a direct benefit of this investment. Nonetheless, this harder-to-find information is precisely the type that is fundamental to enhance the perceived value creation of these networks, because it is probably not just information but tacit knowledge and experience which is required (or made implicit), which at the moment is being kept only on one side of the current distribution model.

Drawing upon the findings from both the quantitative and qualitative analysis, and considering the three dimensions of networks from Neergaard et al. (2005), a framework of value dimensions of SEN is proposed in Figure 3.

\section{Insert Figure 3 here}

The framework illustrates the three dimensions of a SEN, content, structure and interaction, and describes what can determine value in each of them, as perceived by members of SEs. As indicated by Neergaard et al. (2005), it is the interplay between these three dimensions of the network that can provide a more comprehensive understanding of its impact. The first dimension, content, was assessed empirically in this study confirming its importance in the frequency of use of the SEN in regards to quality of information. Certain characteristics, such as, the relevance and practicality of the information offered were essential in determining the value offered by SENs. Moreover, the qualitative analysis highlighted two important elements that provide meaning for members of SEs to establish a relationship with the network: knowledge sharing and emotional support. Both elements illustrate the sense of collectiveness embedded in the SE sector, which differentiate it from private enterprises. It is suggested in entrepreneurial literature that, in emerging fields, traditional business owners are not normally able to leverage collectiveness existing within the field, thus drawing on external fields to grow and establish relationships (Navis and Glynn, 2010). It was evident in the case of SEs that good networks were providing an inclusive context were SEs could share and build their identity. This concurred with SE literature that emphasised the need for SEs to come together to form a SE identity (Ridley-Duff, 2008). A respondent explained:

'Get regular mailouts which are informative and great to feel included in the network, being invited to important events. The communication stresses the feeling of membership and fronting an important cause.'

In regards to the interaction dimension of SENs, value can be created by providing the opportunity for members to interact among themselves, not only with the network organisers, 
and do networking with external organisations and bodies. Optimally, the SEN should not only facilitate networking but also encourage and promote synergies and partnerships. Moreover, the SEN should be supporting the sector by raising awareness of the SE cause. As a respondent expressed:

'We have been to some excellent networking events, including brokerage in between ourselves and other potential customers. I have always found Social Enterprise networks useful and willing to spread the word about what we do.'

The third dimension of the framework is structure, which in the context of social networks refers to the position an individual holds within a network. For SENs, the structural dimension is interpreted as the organisation itself of the network, including its reputation, membership approach and human capital. Regarding the structure and organisation of the SEN, one respondent mentioned:

'The most effective online Social Enterprise Networks are those that are "bottom up" and 2-way allowing inter-communication between support professionals rather than "top down" and one-way dissemination of information. Often a network proves most useful for finding the right source for specific queries. Given that, my answers arrive at "average" as the purpose, quality and ease of access is fluid and dynamic (perhaps the sign of a "living" network).'

This comment concurred with findings from the Office of the Third Sector (OTS) (2007). In their study, they encouraged a bottom-up approach as it provides higher levels of trust and reciprocity. However, they recognised that new bottom-up networks can lack resources that top-down networks can offer so it may find it hard to grow. Reputation of the networks was also considered a determinant of SEN value. Having good relationship with regional and national bodies as well as good administration were mentioned constantly by respondents. For example, one respondent commented

I was recommended to contact them and have been very impressed. SEN seems to be leading the SE sector brand value, intellectually and commercially and has proved very accessible, on top of sector developments and useful for securing and growing our reputation; useful, easy networking with the right people and leading sector thinking.

The three dimensions illustrated in the framework can facilitate inter-communication between members rather than 'top-down' and 'one-way' dissemination of information from providers to users. This is a key element that marks the difference between merely distributive information networks, and collaborative knowledge sharing platforms. The SE sector has the potential to develop new and innovative ways to share knowledge, through knowledge platforms that act on a wider level, and by creating a user generated platform based on 
collaborative rather than distributive knowledge applications. However, this would imply a careful analysis of the existing barriers to sharing knowledge that the sector faces, and an effective action plan to eliminate them, to create an efficient cross-sector knowledge sharing platform.

Traditionally, knowledge management and knowledge sharing have been explored at an intra-organisational level, and not at a cross-sectorial level, where it can have a disruptive impact (Mischen and Jackson, 2008). In terms of SENs, they need to became a knowledge sharing orientated network, where users become active elements of that knowledge generation and distribution, throughout a non-geographically based spectrum.

Technology and especially social media improvements can play a crucial role in this transformation from a distributive to collaborative platform, and in the process of eliminating the technological side of these barriers. But not everything is technology when trying to facilitate knowledge sharing. The management of that knowledge and the interactions between the people actually generating that content is also very important, as is enhancing peer to peer activities, and a clear demonstration of the applicability of the knowledge shared to increase the overall perception of value creation (Mischen and Jackson, 2008).

\section{Conclusions and practical implications}

The SE sector in the UK is a small but growing movement, with numerous needs and a strong desire to keep learning to improve best practices. Due to its social and collective nature, part of their operations are based on networking, thus creating a new participatory culture of collaboration, which should facilitate inter-organisational or cross-sector knowledge management practices. However, this has proven not to be the case all the time, though there is a potential to do so with the existence and use of available SENs.

In new, growing sectors, like that of social innovation and SEs, networks, and more specifically, online networks, play a fundamental role in its development. But the creation of these virtual spaces or knowledge sharing platforms is not enough for that development to happen automatically. The 'what is in it for me' must be very clear, especially when the provision of these networks becomes a paid-for service, and for that it is paramount to understand what motivates users, and what is the perceived value of that use.

It is now possible to conclude that, on one hand, the quantitative findings suggested that value created by SENs in SEs is primarily of an informative nature, and SENs are seen to be more related to communications and keeping the sector informed, rather that facilitating an 
active knowledge exchange between its members. One of the reasons behind it is the sporadic and infrequent use of SENs, as seen through the results of the survey, which shows that most SEs only engage with these networks from three to four times a month, a rate that can be considered insufficient to constitute a proper knowledge sharing network. But most importantly, what affects that usage rate is the perceived utility of the information available, which also denotes a need for more useful and practical information, as well as 'hands-on' tools that SEs can later apply to improve their own organisations. On the other hand, the qualitative analysis provided further insights on how SENs are starting to go beyond only providing information activities, towards facilitating and nurturing interactions and opportunities for collaboration, as well as emotional support and promotion. These insights informed the bases for the proposed framework of value dimensions of SEN presented in this paper.

To enable the development of a more active knowledge sharing community of practice through SENs, a technological and cultural change must take place taking into consideration the structure, content and interaction dimensions of the network. First, SENs need to change their approach from a distributive, one-way system, to a collaborative, two-way system, to affect the way users relate to the network and how the content is generated. Secondly, the technological side of that change implies the implementation of a new type of online platform, which would facilitate that collaborative nature of the exchange. Most significantly, it is the change in the way users will relate to each other in this new scenario that has the power to determine the success or failure of this new approach, providing further opportunities for collaboration and coproduction. Thirdly, for a successful outcome more peer-to-peer activities should be promoted to develop confidence and increase the trust between SENs' members. Eventually this will be the only way to foster adequate sociocultural factors that will make possible the creation of a cross-sector knowledge sharing platform for the SE Sector.

In addition to this technological and cultural change, government promotional efforts, in the form of financial or public policy efforts, can support the development of formal networks and a more solid business support system. Governments are trying to develop networks to support the growth of SEs with the creation of intermediate agencies, such as, national and regional networks (Ridley-Duff and Bull, 2011). But more support needs to be provided since these networks can facilitate collaboration, which is a key element in sustainability of SEs.

Finally, the practice of informational networking and collaborative knowledge sharing, constitute a very important social transformation, which has the potential to achieve 
significant changes in society. Because of the ethos behind SEs, these new organisations seem to be the perfect match to put in place these transformational changes, and initiate a new social epoch through the practice of business.

\section{Limitations and future research}

This research was carried out by a random and voluntary survey of the potential organisations in the UK and thus it cannot be certain that a complete sample of all types and sectors were covered. In addition, this was a survey carried out only in the UK and, thus, some of the findings may not apply to Europe-wide, or indeed in the USA, where SEs operate in a different organisational format. The implications of the findings and the limitations of the study mean that further case-based studies are now required to discover what might cause improved tacit knowledge sharing within the SEN and SEs, as well as the role of SEN in encouraging and facilitative collaboration among SEs. Studies across Europe and the US would also add to these findings.

\section{References}

Alter, S.K. (2003), Social Enterprise: A Typology of the Field Contextualized in Latin America, Book, Inter-American Development Bank, Washington D.C.

Austin, J., Stevenson, H. and Wei-Skillern, J. (2006), "Social and Commercial Entrepreneurship: Same, Different, or Both?", Entrepreneurship: Theory \& Practice, Wiley-Blackwell, Vol. 30 No. 1, pp. 1-22.

Battilana, J. and Lee, M. (2014), "Advancing Research on Hybrid Organizing - Insights from the Study of Social Enterprises", The Academy of Management Annals, Vol. 8 No. May 2015, pp. 1-44.

Bryman, A. and Bell, E. (2015), Business Research Methods, BOOK, Oxford University Press, Oxford, UK.

Burt, R.S. (1997), "A note on social capital and network content”, Social Networks, JOUR, , Vol. 19 No. 4, pp. 355-373.

Cabinet Office. (2016), Social Enterprise: Market Trends 2014, available at: https://www.gov.uk/government/publications/social-enterprise-market-trends-2014 (accessed 28 November 2016).

Christopoulos, D. and Vogl, S. (2015), "The Motivation of Social Entrepreneurs: The Roles, Agendas and Relations of Altruistic Economic Actors", Journal of Social Entrepreneurship, JOUR, Routledge, Vol. 6 No. 1, pp. 1-30.

Creswell, J.W. (2014), Research Design: Qualitative, Quantitative, and Mixed Methods Approaches, Fourth edi., Sage Publications Ltd, London. 
Creswell, J.W. and Plano Clark, V.L. (2011), Designing and Conducting Mixed Methods Research, 2nd ed., Book, Sage Publications Ltd., London.

Dart, R. (2004), "The legitimacy of Social Enterprise", NonProfit Management and Leadership, Journal Article, , Vol. 14 No. 4, pp. 411-424.

Defourny, J. and Nyssens, M. (2006), “Defining social enterprise”, in Nyssens, M. (Ed.), Social Enterprise: At the Crossroads of Market, Public Policies and Civil Society, Book Section, Routledge, London, pp. 3-26.

Defourny, J. and Nyssens, M. (2010), "Conceptions of Social Enterprise and Social Entrepreneurship in Europe and the United States: Convergences and Divergences", Journal of Social Entrepreneurship, Journal Article, , Vol. 1 No. 1, pp. 32-53.

Dixon, S.E.A. and Clifford, A. (2007), "Ecopreneurship - a new approach to managing the triple bottom line", Journal of Organizational Change Management, Journal Article, , Vol. 20 No. 3, pp. 326-345.

Doherty, B., Haugh, H. and Lyon, F. (2014), "Social enterprises as hybrid organizations: A review and research agenda", International Journal of Management Reviews, Vol. 16 No. 4, pp. 417-436.

Di Domenico, M., Haugh, H. and Tracey, P. (2010), "Social Bricolage: Theorizing Social Value Creation in Social Enterprises", Entrepreneurship: Theory \& Practice, Journal Article, Wiley-Blackwell, Vol. 34 No. 4, pp. 681-703.

DTI. (2002), Social Enterprise: A Strategy for Success, Report, Department of Trade and Industry, London, available at:

http://www.cabinetoffice.gov.uk/third_sector/social_enterprise/action_plan.aspx.

Ebrahim, A., Battilana, J. and Mair, J. (2014), "The governance of social enterprises: Mission drift and accountability challenges in hybrid organizations", Research in Organizational Behavior, Elsevier Ltd, Vol. 34, pp. 81-100.

Farmer, J., Hill, C. and Muñoz, S.-A. (2012), Community Co-Production: Social Enterprise in Remote and Rural Communities, BOOK, Edward Elgar Publishing Limited, Cheltenham, UK.

Freeman, J., Carroll, G.R. and Hannan, M.T. (1983), "The Liability of Newness: Age Dependence in Organizational Death Rates", American Sociological Review, JOUR, [American Sociological Association, Sage Publications, Inc.], Vol. 48 No. 5, pp. 692710.

Gioia, D.A., Corley, K.G. and Hamilton, A.L. (2013), "Seeking Qualitative Rigor in Inductive Research: Notes on the Gioia Methodology ", Organizational Research Methods , JOUR, , Vol. 16 No. 1, pp. 15-31.

Granados, M.L., Mohamed, S. and Hlupic, V. (2016), "Knowledge Management activities in Social Enterprises: lessons for small and non-profit firms", Journal of Knowledge 
Management, Vol. xx No. xx, p. xx.

Greve, A. and Salaff, J.W. (2003), "Social Networks and Entrepreneurship", Entrepreneurship Theory and Practice, JOUR, Blackwell Publishing Ltd., Vol. 28 No. 1, pp. 1-22.

Hair, J.F.J., Black, W.C., Babin, B.J. and Anderson, R.E. (2010), Multivariate Data Analysis : A Global Perspective, 7th ed., Book, Pearson Education , Upper Saddle River, N.J. Haugh, H. (2005), "A research agenda for social entrepreneurship", Social Enterprise Journal, Journal Article, , Vol. 1 No. 1, pp. 1-12.

Haugh, H. (2007), “Community-Led Social Venture Creation”, Entrepreneurship: Theory \& Practice, Journal Article, Wiley-Blackwell, Vol. 31 No. 2, pp. 161-182.

Haveman, H.A. and Rao, H. (2006), "Hybrid Forms and the Evolution of Thrifts", American Behavioral Scientist, JOUR, , Vol. 49 No. 7, pp. 974-986.

Hazenberg, R., Bajwa-Patel, M., Mazzei, M., Roy, M.J. and Baglioni, S. (2016), "The role of institutional and stakeholder networks in shaping social enterprise ecosystems in Europe", Social Enterprise Journal, JOUR, Emerald, available at:https://doi.org/10.1108/SEJ-10-2016-0044.

Henry, C. (2015), "Doing Well by Doing Good: Opportunity Recognition and the Social Enterprise Partnership", Journal of Social Entrepreneurship, JOUR, Routledge, Vol. 6 No. 2, pp. 137-160.

Hines, F. (2005), "Viable social enterprise: an evaluation of business support to social enterprises", Social Enterprise Journal, Journal Article, , Vol. 1 No. 1, pp. 13-28.

Hoang, H. and Antoncic, B. (2003), "Network-based research in entrepreneurship", Journal of Business Venturing, Vol. 18 No. 2, pp. 165-187.

Hockerts, K. (2006), "Entrepreneurial opportunity in social purpose business ventures", in Mair, J., Robertson, J. and Hockerts, K. (Eds.), Social Entrepreneurship, Book Section, Palgrave Macmillan, New York, pp. 142-154.

Hoogendoorn, B., Pennings, E. and Thurik, A.R. (2010), "What do we know about social entrepreneurship: An analysis of empirical research", International Review of Entrepreneurship, Journal Article, , Vol. 8 No. 2, pp. 1-42.

Hormiga, E., Batista-Canino, R.M. and Sanchez-Medina, A. (2011), "The Impact of Relational Capital on the Success of New Business Start-Ups”, Journal of Small Business Management, Vol. 49 No. 4, pp. 617-638.

Jackson, K.M. and Trochim, W.M.K. (2002), "Concept Mapping as an Alternative Approach for the Analysis of Open-Ended Survey Responses", Organizational Research Methods , JOUR, , Vol. 5 No. 4, pp. 307-336.

Kerlin, J.A. (2009), “Social enterprise: A global comparison”, Edited Book, Tufts University Press, Lebanon, $\mathrm{NH}$. 
Kerlin, J.A. (2010), "A Comparative Analysis of the Global Emergence of Social Enterprise", Voluntas: International Journal of Voluntary and Nonprofit Organizations, Journal Article, Springer Netherlands, Vol. 21 No. 2, pp. 162-179.

Krippendorff, K. (2012), Content Analysis: An Introduction to Its Methodology, Third., BOOK, Sage Publications Limited, London.

Leahy, G. and Villeneuve-Smith, F. (2009), State of Social Enterprise Survey 2009, Report, Social Enterprise Coalition, London.

Lee, Y.W., Strong, D.M., Kahn, B.K. and Wang, R.Y. (2002), "AIMQ: a methodology for information quality assessment", Information \& Management, JOUR, , Vol. 40 No. 2, pp. 133-146.

Leonard-Barton, D. (1995), Wellsprings of Knowledge: Building and Sustaining the Sources of Innovation, Book, Harvard Business School Press, Boston, MA.

Lyon, F. and Ramsden, M. (2006), "Developing fledgling social enterprises? A study of the support required and means of delivering it", Social Enterprise Journal, Journal Article, , Vol. 2 No. 1, pp. 27-41.

Martin, F. and Thompson, M. (2010), Social Enterprise; Developing Sustainable Businesses, Palgrave Macmillan, London.

Mawson, J. (2010), "Social enterprise, strategic networks and regional development: The West Midlands experience", International Journal of Sociology and Social Policy, JOUR, Emerald, Vol. 30 No. 1/2, pp. 66-83.

Meyskens, M., Carsrud, A.L. and Cardozo, R.N. (2010), "The symbiosis of entities in the social engagement network: The role of social ventures", Entrepreneurship \& Regional Development: An International Journal, Journal Article, , Vol. 22 No. 5, pp. 425-455.

Miller, H. (1996), "The multiple dimensions of information quality", Information Systems Management, JOUR, Taylor \& Francis, Vol. 13 No. 2, pp. 79-82.

Milton, N.R. (2007), Knowledge Acquisition in Practice: A Step-by-Step Guide, Book, Springer-Verlag London Limited, London.

Mischen, P.A. and Jackson, S.K. (2008), "Connecting the dots: applying complexity theory, knowledge management and social network analysis to policy implementation", Public Administration Quarterly, JOUR, SPAEF, Vol. 32 No. 3, pp. 314-338.

Navis, C. and Glynn, M.A. (2010), "How New Market Categories Emerge: Temporal Dynamics of Legitimacy, Identity, and Entrepreneurship in Satellite Radio, 1990-2005", Administrative Science Quarterly, JOUR, , Vol. 55 No. 3, pp. 439-471.

Neergaard, H., Shaw, E. and Carter, S. (2005), "The impact of gender, social capital and networks on business ownership: a research agenda", International Journal of Entrepreneurial Behavior \& Research, JOUR, Emerald, Vol. 11 No. 5, pp. 338-357. Office of the Third Sector (OTS). (2007), Review of Social Enterprise Networks, London. 
Pallant, J. (2013), SPSS Survival Manual, BOOK, McGraw-Hill Education (UK).

Peattie, K. and Morley, A. (2008), "Eight paradoxes of the social enterprise research agenda", Social Enterprise Journal, Journal Article, , Vol. 4 No. 2, pp. 91-107.

Ridley-Duff, R. (2008), "Social enterprise as a socially rational business", International Journal of Entrepreneurial Behavior \& Research, JOUR, Emerald, Vol. 14 No. 5, pp. 291-312.

Ridley-Duff, R. and Bull, M. (2011), Understanding Social Enterprise: Theory and Practice, Book, Sage Publications, London.

Ruef, M. and Scott, W.R. (1998), "A Multidimensional Model of Organizational Legitimacy: Hospital Survival in Changing Institutional Environments", Administrative Science Quarterly, JOUR, [Sage Publications, Inc., Johnson Graduate School of Management, Cornell University], Vol. 43 No. 4, pp. 877-904.

Santos, F.M. (2012), "A Positive Theory of Social Entrepreneurship", Journal of Business Ethics, Vol. 111 No. 3, pp. 335-351.

Seelos, C., Mair, J., Battilana, J. and Dacin, M.T. (2011), "The Embeddedness of Social Entrepreneurship: Understanding Variation across Local Communities”, Communities and Organizations, Vol. 33, CHAP, Emerald Group Publishing Limited, pp. 333-363.

Shah, D. (2009), "Social Enterprise in practice: A UK policy perspective: thought piece from the UK Social Enterprise Coalition", Social Enterprise Journal, Journal Article, , Vol. 5 No. 2, pp. 104-113.

Sharir, M. and Lerner, M. (2006), "Gauging the success of social ventures initiated by individual social entrepreneurs", Journal of World Business, Journal Article, , Vol. 41 No. 1, pp. 6-20.

Shaw, E. and Carter, S. (2007), "Social entrepreneurship: Theoretical antecedents and empirical analysis of entrepreneurial processes and outcomes", Journal of Small Business and Enterprise Development, Journal Article, , Vol. 14 No. 3, pp. 418-434.

Smyth, J.D., Dillman, D.A., Christian, L.M. and Mcbride, M. (2009), "Open-Ended Questions in Web Surveys: Can Increasing the Size of Answer Boxes and Providing Extra Verbal Instructions Improve Response Quality? ", Public Opinion Quarterly, JOUR, , Vol. 73 No. 2, pp. 325-337.

Spear, R. (2006), "Social entrepreneurship: a different model? ", International Journal of Social Economics, Journal Article, , Vol. 33 No. 5/6, pp. 399-411.

Stalder, F. (2006), Manuel Castells: The Theory of the Network Society, BOOK, Polity.

Stam, W., Arzlanian, S. and Elfring, T. (2014), "Social capital of entrepreneurs and small firm performance: A meta-analysis of contextual and methodological moderators", Journal of Business Venturing, Vol. 29 No. 1, pp. 152-173.

Tashakkori, A. and Teddlie, C. (2010), "Sage Handbook of Mixed Methods in Social \& 
Behavioral Research", Edited Book, Sage Publications, Inc, London.

Teasdale, S. (2012), "What's in a Name? Making Sense of Social Enterprise Discourses", Public Policy and Administration, JOUR, , Vol. 27 No. 2, pp. 99-119.

Teasdale, S., Lyon, F. and Baldock, R. (2013), "Playing with Numbers: A Methodological Critique of the Social Enterprise Growth Myth", Journal of Social Entrepreneurship, Taylor \& Francis Group , Vol. 4 No. 2, pp. 113-131.

Teece, D.J., Pisano, G. and Shuen, A. (1997), "Dynamic capabilities and strategic management", edited by Dosi, G., Nelson, R.R. and Winter, S.G.Strategic Management Journal, John Wiley \& Sons, Vol. 18 No. 7, pp. 509-533.

Thema, M.-W., Kerlin, J.A. and Zook, S. (2015), "A quantitative critique of Kerlin's macroinstitutional social enterprise framework", Social Enterprise Journal, JOUR, Emerald, Vol. 11 No. 2, pp. 178-201.

Villeneuve-Smith, F. and Temple, N. (2015), State of Social Enterprise Survey 2015, Report, Social Enterprise UK, London.

Weber, C., Wallace, J. and Tuschke, A. (2013), "Social capital, social innovation and social impact", Frontiers of Entrepreneurship Research, JOUR, , Vol. 33 No. 18, p. 5.

Yli-Renko, H., Autio, E. and Sapienza, H.J. (2001), "Social capital, knowledge acquisition, and knowledge exploitation in young technology-based firms", Strategic Management Journal, Journal Article, John Wiley \& Sons, Ltd., Vol. 22 No. 6-7, pp. 587-613. 


\section{Table 1 - Descriptive analysis of general questions}

\begin{tabular}{|c|c|c|}
\hline Question & Frequency & $\begin{array}{c}\text { Percent } \\
\text { from total } \\
\text { responses }\end{array}$ \\
\hline \multicolumn{3}{|l|}{ SEN choice criteria (Choose as many as applicable) } \\
\hline $\begin{array}{l}\text { 1. Local/regionally based (as per your } \\
\text { organisation) }\end{array}$ & 132 & 54.8 \\
\hline 2. Wide UK Coverage & 91 & 37.8 \\
\hline 3. Availability of publications & 61 & 25.3 \\
\hline 4. Prestige of the brand & 53 & 22.0 \\
\hline 5. Number of activities they organise in a year & 38 & 15.8 \\
\hline \multicolumn{3}{|l|}{ Purpose of use (Choose as many as applicable) } \\
\hline 1. Obtaining sector news & 171 & 71.2 \\
\hline 2. Developing your contacts & 122 & 50.6 \\
\hline 3. Latest research and reports on Social Enterprise & 113 & 46.9 \\
\hline $\begin{array}{l}\text { 4. Access to new options of funding and finance } \\
\text { for your Social Enterprise }\end{array}$ & 103 & 42.7 \\
\hline $\begin{array}{l}\text { 5. Workshops and other activities to improve } \\
\text { personal skills/knowledge }\end{array}$ & 97 & 40.2 \\
\hline \multicolumn{3}{|l|}{$\begin{array}{l}\text { Networks value creation (Choose as many as } \\
\text { applicable) }\end{array}$} \\
\hline $\begin{array}{l}\text { 1. They keep the sector informed of the latest } \\
\text { news. }\end{array}$ & 160 & 66.4 \\
\hline $\begin{array}{l}\text { 2. They generate a platform for knowledge sharing } \\
\text { and knowledge creation that is fundamental for } \\
\text { the future development of the Social Enterprise } \\
\text { movement in the UK. }\end{array}$ & 116 & 48.1 \\
\hline $\begin{array}{l}\text { 3. They allow members to communicate more } \\
\text { easily. }\end{array}$ & 113 & 46.9 \\
\hline $\begin{array}{l}\text { 4. They facilitate access to new sources of finance } \\
\text { and funding. }\end{array}$ & 104 & 43.2 \\
\hline
\end{tabular}


Table 2 - Descriptive and Multivariate analysis

\begin{tabular}{|c|c|c|c|c|c|c|c|}
\hline \multirow[b]{2}{*}{ Variable } & \multicolumn{4}{|c|}{ Pearson correlations } & \multirow[t]{2}{*}{$\beta$} & \multirow[t]{2}{*}{$s r^{2}$} & \multirow[t]{2}{*}{$b$} \\
\hline & $\begin{array}{c}\text { Freque } \\
\text { ncy }\end{array}$ & $\begin{array}{c}\text { Usefuln } \\
\text { ess }\end{array}$ & Quality & $\begin{array}{c}\text { Ease of } \\
\text { use }\end{array}$ & & & \\
\hline Frequency & & & & & $1.643^{*}$ & .000 & \\
\hline Usefulness & $.505^{\star}$ & & & & $.396^{*}$ & .000 & .371 \\
\hline Quality & $.445^{*}$ & $.703^{*}$ & & & .48 & .765 & .036 \\
\hline Ease of use & $.435^{*}$ & $.612^{*}$ & $.833^{*}$ & & .231 & .101 & .178 \\
\hline Mean & 3.20 & 2.33 & 2.25 & 2.26 & & & \\
\hline$S D$ & 1.14 & 1.08 & 0.86 & 0.88 & $\begin{array}{r}\text { Adju } \\
\text { Durbin- }\end{array}$ & $\begin{array}{l}\text { ed } R^{2}= \\
\text { latson= }\end{array}$ & $\begin{array}{l}.270 \\
1.875\end{array}$ \\
\hline
\end{tabular}

18

19

20

21

22

23

24

25 
Figure 1 - Analysis of negative perceptions of value (open-ended question)

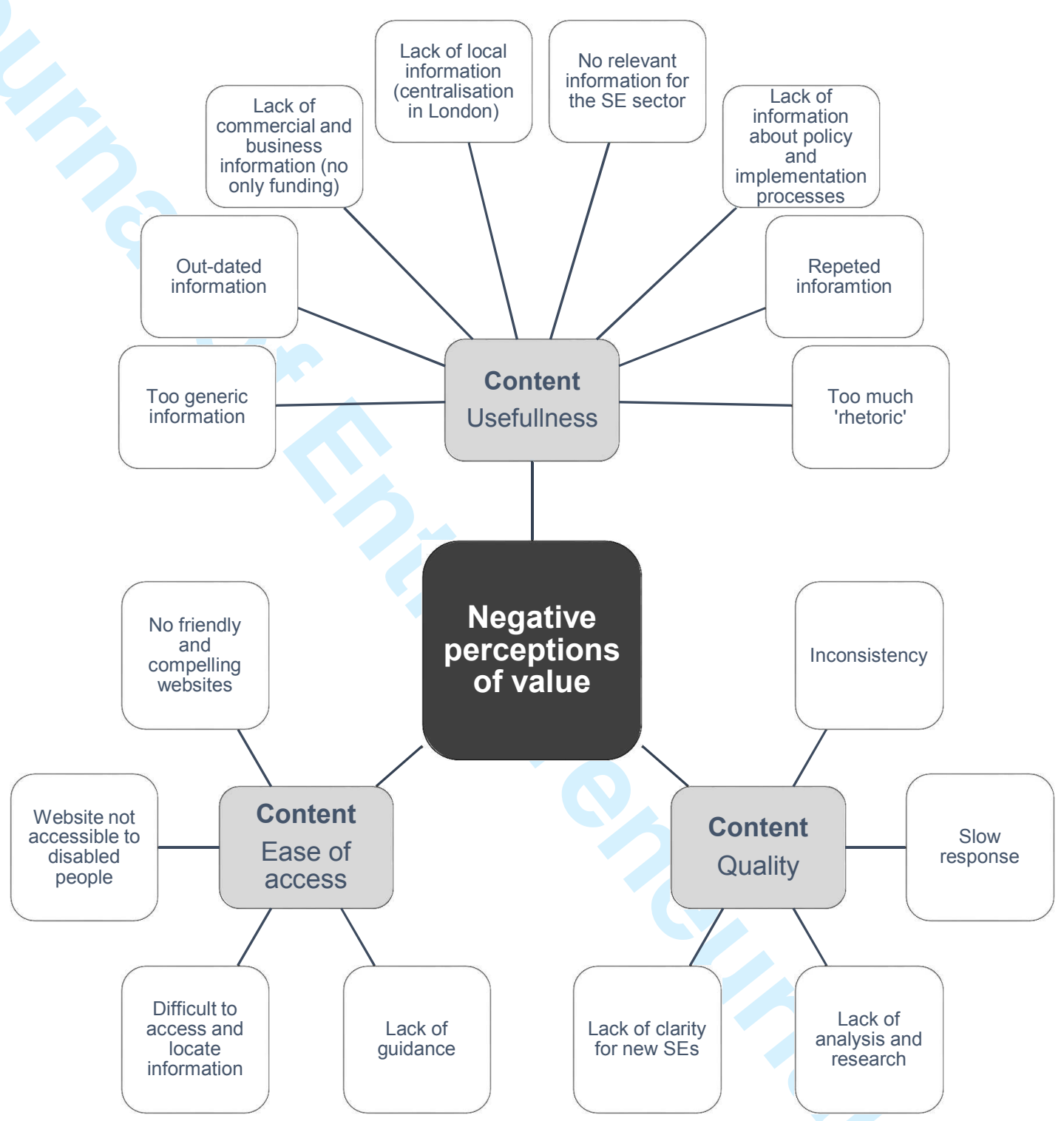


Figure 2 - Analysis of positive perceptions of value (open-ended question) 
Figure 3 - Framework for value dimensions of social enterprise networks

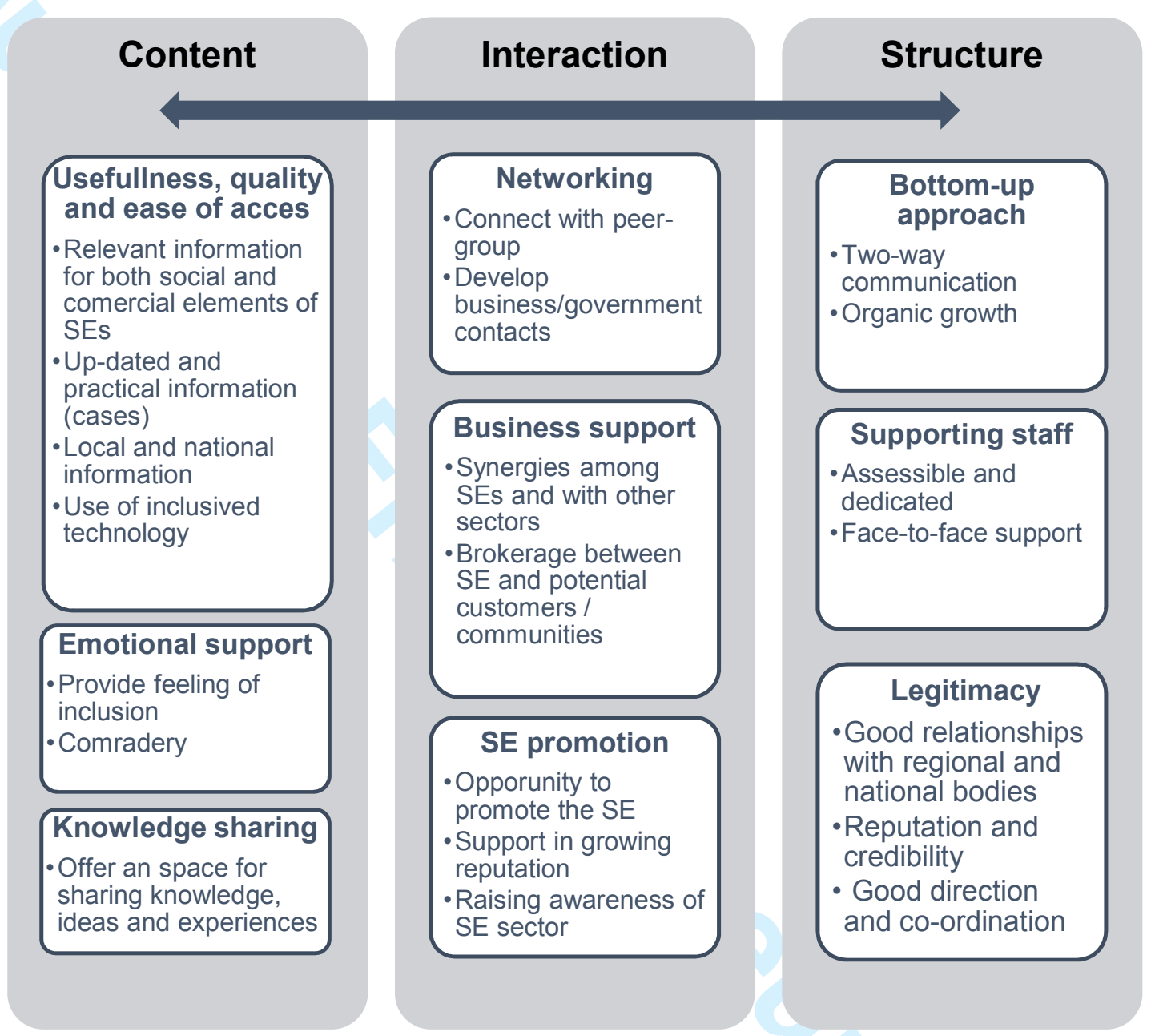

